\title{
MORTALITY DUE TO TRANSPORT ACCIDENTS IN THE CITY OF SÃO PAULO: 2005-2015
}

\section{MORTALIDADE POR ACIDENTES DE TRANSPORTE NO MUNICÍPIO DE SÃO PAULO: 2005-2015}

\author{
Fábio Boucault Tranchitella ${ }^{1}$ (i), Renata Souza dos Santos ${ }^{1}$ (i), Jamill Jamel Sakr Hussein El Bacha ${ }^{1}$ (D), \\ Júlia Villibor Sobrado ${ }^{1}$ (1), Matheus bortoloci Sampalo dos Santos ${ }^{1}$ (i), Patrícia Colombo Souza ${ }^{1}$ (1)
}

1. Universidade Santo Amaro, São Paulo, SP, Brasil.

\section{ABSTRACT}

Objective: To characterize cases of land transport accidents in the macro-regions of city of São Paulo in 2005, 2010, and 2015. Methods: This is a population-based, longitudinal and retrospective study of time series, based on a quantitative survey of land transport accidents that occurred in the city of São Paulo in 2005, 2010 and 2015 using data from the Mortality Information System of the City of São Paulo. Results: A total of 1,343, 1,567 and 1,088 deaths by accident recorded in the city' population in the years 2005, 2010 and 2015 respectively. The highest occurrences were in the age groups 15 to 24 years and 24 to 34 years. The highest number of deaths due to accidents was among males. The mortality rates observed in the macro-regions were South (23.8\%), East (22\%), North (21.6\%), West (7.1\%), and Center (3\%). In comparing the years examined, there was a decline in the mortality rate per 100,000 inhabitants in most macro-regions. Conclusion: Despite the decrease in overall accident mortality in most macro-regions, it still deserves attention on preventive traffic actions focused on young males living in peripheral neighborhoods, since they represent the most susceptible group. Level of evidence II; Retrospective Study.

Keywords: Accidents, Traffic. Mortality. Accident Prevention.

\section{RESUMO}

Objetivo: Caracterizar os casos de acidentes de transporte terrestre nas macrorregiões do município de São Paulo nos anos de 2005, 2010 e 2015. Métodos: Trata-se de estudo de base populacional, longitudinal e retrospectivo de séries temporais, embasado em um levantamento quantitativo dos acidentes de transporte terrestres ocorridos no município de São Paulo nos anos de 2005, 2010 e 2015, utilizando dados provenientes do Sistema de Informações sobre Mortalidade. Resultados: Um total de 1.343, 1.567 e 1.088 óbitos por acidente foram registrados para a população do município nos anos de 2005, 2010 e 2015, respectivamente. A maior ocorrência se deu nas faixas etárias de 15 a 24 anos e 24 a 34 anos. O maior número de mortes por acidentes se deu no sexo masculino. As taxas de mortalidade observadas nas macrorregiões foram: Sul (23,8\%), Leste (22\%), Norte (21,6\%), Oeste (7,1\%) e Centro (3\%). Comparando-se períodos, houve queda nos coeficientes padronizados de mortalidade geral por 100 mil habitantes na maioria das macrorregiões. Conclusão: Apesar da queda na mortalidade geral dos acidentes na maioria das macrorregiões, ela ainda merece atenção e foco em ações de trânsito preventivas direcionadas aos jovens do sexo masculino que residem em bairros periféricos, pois representam o grupo mais suscetível. Nível II - Estudo prognóstico - Investigação do efeito de características de um paciente sobre o desfecho da doença. Nível de Evidência II; Estudo retrospectivo.

Citation: Tranchitella FB, Santos RS, El Bacha JJSH, Sobrado JV, Santos MBS, Colombo-Souza P. Mortality for transport accidents in the municipality of São Paulo: 2005-2015. Acta Ortop Bras. [online]. 2021;29(4):193-196. Available from URL: http://www.scielo.br/aob.

\section{INTRODUCTION}

Traffic accidents represent a serious global public health problem. The World Health Organization (WHO) estimates that the annual number of deaths from land transport accidents (LTA) is 1.24 million people, mostly from middle-income countries. ${ }^{1}$ It is estimated that if no action is taken to reverse this scenario, by 2020 traffic deaths could reach 1.9 million people worldwide and become the 5th leading cause of death in 2030., ${ }^{2,3}$
Worldwide, $77 \%$ of traffic deaths occur among the young male population. Accidents represent the leading cause of death among men aged 15 to 29 years; and the 3rd cause among those aged 30 to 49 years. ${ }^{1}$ Regarding the victim category, occupants of motor vehicles, followed by pedestrians and motorcyclists are at the most risk, accounting for $36 \%, 35 \%$, and $16 \%$ respectively of all traffic deaths. ${ }^{2,4}$

In Brazil, from 1996 to 2015, 21,057,086 people died, of which $2,656,875$ were due to External Causes (12.6\%). Among the external

All authors declare no potential conflict of interest related to this article.

The study was conducted at Universidade Santo Amaro, SP, Brasil.

Correspondence: Patrícia Colombo de Souza. Rua Prof. Enéas de Siqueira Neto 340, São Paulo, SP, Brasil. 04829300. e-mail: pcolombo@prof.unisa.br 
causes, LTA appear as the second most prevalent cause, being responsible for the deaths of 733,120 people (27.6\% of deaths by cause and $3.5 \%$ of total deaths in the period). ${ }^{5}$

Traffic accidents have a significant impact on the country's economy, not only due to the high costs of care and hospitalization of victims, but also because it is responsible for the death of a significant portion of the economically active population. ${ }^{6}$ Several factors may contribute to the occurrence of these accidents, such as inadequate enforcement of traffic laws, the increase in the vehicle fleet, and the consumption of alcoholic beverages. In addition, the association between alcohol consumption and non-use of safety equipment has been appointed as more prevalent among men from 22 to 45 years old. 7,8

The damage to health resulting from these accidents can reach various dimensions, resulting in physical and emotional repercussions that reduce the quality of life at both individual and collective levels and generate an overload on health services. External causes demand more complex hospital procedures, such as higher number of surgeries, the need for intensive care, drug consumption, and multidisciplinary support, bringing higher costs to health services. ${ }^{4}$

Considering these perspectives and the importance of LTA for the occurrence of deaths, the aim of this study was to characterize the cases of LTA in the macro-regions of the city of São Paulo in the years 2005, 2010, and 2015.

\section{METHOD}

This is a population-based, longitudinal and retrospective study of time series, based on a quantitative survey of LTAs that occurred in the city of São Paulo in 2005, 2010 and 2015. We used data from the Mortality Information System of the City of São Paulo, which processed the declarations of deaths that occurred in the city, using as a base document the Death certificate (DC), completed and signed by a physician. LTA were considered to be pedestrian and cyclist collisions; trauma in accidents involving motorcyclists and the remaining transport accidents. ${ }^{9}$

Due to the probable changes that occurred in each of the populations in the time elapsed between 2000 and 2015, we proposed the calculation of the standard median population for each year of information collection.

In comparing populations, the mortality coefficient was standardized to correct distortions resulting from possible differences in its composition linked to attributes or variables that are related to the probability of death. ${ }^{10}$

We selected all deaths related to LTA in the population residing in the city of São Paulo and stratified them by sex (male or female), age group (WHO criterion, every 5 years), macro-regions of the city (south, southeast, east, center, west and north) and years of occurrence (2005, 2010 and 2015).

The choice of the median of the percentages of participation, instead of the arithmetic mean, aimed to remove the bias that the latter could bring due to the possible occurrence, in certain populations, of percentages of participation that strongly differ from the others. Considering this alteration, all regions had their coefficient of occurrence standardized, following the constitution of the median standard population. ${ }^{11}$ Since we have six regions, the median was represented by the average of the populations situated in the 3rd and 4th positions of the order of populations in ascending order. The median was calculated for each of the years considered in the study (Table 1).
Table 1. Regions of the City of São Paulo according to the median population and respective positions $(P)$ in ascending order in the years 2005, 2010 and 2015

\begin{tabular}{c|c|c|c|c|c|c}
\hline Region & $\mathbf{P}$ & $\mathbf{2 0 0 5}$ & $\mathbf{P}$ & $\mathbf{2 0 1 0}$ & $\mathbf{P}$ & $\mathbf{2 0 1 5}$ \\
\hline South & $\mathbf{4}$ & $2,408,507$ & 5 & $2,551,020$ & 5 & $2,684,981$ \\
\hline East & 5 & $2,326,697$ & $\mathbf{4}$ & $2,379,685$ & $\mathbf{4}$ & $2,441,615$ \\
\hline Southeast & 6 & $2,596,056$ & 6 & $2,648,640$ & 6 & $2,686,027$ \\
\hline West & 2 & 973,558 & 2 & $1,022,564$ & 2 & $1,055,106$ \\
\hline Center & 1 & 403,220 & 1 & 430,599 & 1 & 448,565 \\
\hline North & $\mathbf{3}$ & $2,158,535$ & $\mathbf{3}$ & $2,213,477$ & $\mathbf{3}$ & $2,265,504$ \\
\hline Median pop. & & $\mathbf{2 , 2 4 2 , 6 1 6}$ & & $\mathbf{2 , 2 9 6 , 5 8 1}$ & & $\mathbf{2 , 3 5 3 , 5 5 9}$ \\
\hline
\end{tabular}

Once the median populations were established the value of the standardized coefficient (PC\%) of occurrence corresponding to the ATTs was calculated, for each year, following the standard population, using the expression: number of events $x 100,000$ inhabitants/standard median population.

For the analysis of the results, we applied the Chi-square test to compare the regions of the city in relation to the percentage of LTA for the years 2005, 2010, and 2015. The significance level was established at 0.05 .

\section{RESULTS}

A total of $1,343,1,567$ and 1088 deaths from LTA were registered for the population of the city of São Paulo in the years 2005, 2010 and 2015, respectively.

According to Table 2, the age groups between 15 to 24 years and 24 to 34 years presented the highest number of occurrences, totaling $43.4 \%$ of the cases, followed by the age group 35 to 44 years with $15 \%$ of the records and 45 to 54 years with an average of $12 \%$. Age groups above and below these marks presented less than $10 \%$ of the cases. We also verified males presented the highest number of deaths by accidents on average in the 3 years examined, corresponding to $78.9 \%$ of the cases, against only $21.1 \%$ of the deaths of females.

Table 2. Sociodemographic characterization of those involved in LTA that occurred in the regions of the municipality of São Paulo in the years 2005, 2010 and 2015.

\begin{tabular}{c|c|c|c|c|c|c}
\hline $\begin{array}{c}\text { Sociodemographic } \\
\text { data }\end{array}$ & \multicolumn{2}{|c|}{$\mathbf{2 0 0 5}$} & \multicolumn{2}{c|}{$\mathbf{2 0 1 0}$} & \multicolumn{2}{c}{$\mathbf{2 0 1 5}$} \\
\hline Age group & $\mathbf{N}$ & $\%$ & $\mathbf{N}$ & $\%$ & $\mathbf{N}$ & $\%$ \\
\hline$<1$ & 2 & 0.18 & 3 & 0.2 & 1 & 0.09 \\
\hline 1 to 4 & 15 & 1,2 & 6 & 0.4 & 9 & 0.8 \\
\hline 5 to 14 & 53 & 4.0 & 45 & 2.9 & 28 & 2.6 \\
\hline 15 to 24 & 318 & 23.9 & 337 & 22.0 & 250 & 23.0 \\
\hline 25 to 34 & 267 & 20.1 & 346 & 22.5 & 201 & 18.5 \\
\hline 35 to 44 & 203 & 15.3 & 229 & 14.9 & 167 & 15.4 \\
\hline 45 to 54 & 169 & 12.7 & 204 & 13.3 & 120 & 11.0 \\
\hline 55 to 64 & 86 & 6.5 & 127 & 8.2 & 128 & 11.8 \\
\hline 65 to 74 & 110 & 8.2 & 112 & 7.3 & 92 & 8.4 \\
\hline 75 and + & 105 & 7.9 & 128 & 8.3 & 91 & 8.4 \\
\hline TOTAL & $\mathbf{1 , 3 2 8}$ & 100.0 & $\mathbf{1 , 5 3 7}$ & 100.0 & $\mathbf{1 , 0 8 7}$ & \\
\hline Gender & $\mathbf{N}$ & $\%$ & $\mathbf{N}$ & $\%$ & $\mathbf{N}$ & 100.0 \\
\hline Female & 297 & 22.2 & 302 & 19.3 & 236 & 21.7 \\
\hline Male & 1046 & 77.8 & 1265 & 80.7 & 852 & 78.3 \\
\hline TOTAL & $\mathbf{1 , 3 4 3}$ & 100.0 & $\mathbf{1 , 5 6 7}$ & 100.0 & $\mathbf{1 , 0 8 8}$ & 100.0 \\
\hline REGION & $\mathbf{N}$ & $\%$ & $\mathbf{N}$ & $\%$ & $\mathbf{N}$ & $\%$ \\
\hline Center & 29 & 2.3 & 50 & 3.4 & 35 & 3.2 \\
\hline West & 281 & 22.4 & 314 & 22.1 & 263 & 24.2 \\
\hline & & & & &
\end{tabular}


Table 2. Sociodemographic characterization of those involved in LTA that occurred in the regions of the municipality of São Paulo in the years 2005, 2010 and 2015.

\begin{tabular}{c|c|c|c|c|c|c}
\hline $\begin{array}{c}\text { Sociodemographic } \\
\text { data }\end{array}$ & \multicolumn{2}{|c|}{$\mathbf{2 0 0 5}$} & \multicolumn{2}{c|}{$\mathbf{2 0 1 0}$} & \multicolumn{2}{c}{$\mathbf{2 0 1 5}$} \\
\hline North & 277 & 22.1 & 304 & 21.3 & 234 & 21.5 \\
\hline West & 76 & 6.0 & 91 & 6.4 & 97 & 8.9 \\
\hline Southeast & 290 & 21.1 & 321 & 22.5 & 210 & 19.3 \\
\hline South & 302 & 24.1 & 347 & 24.3 & 249 & 22.9 \\
\hline TOTAL & $\mathbf{1 , 2 5 5}$ & $\mathbf{1 0 0 . 0}$ & $\mathbf{1 , 4 2 7}$ & $\mathbf{1 0 0 . 0}$ & $\mathbf{1 , 0 8 8}$ & $\mathbf{1 0 0 . 0}$ \\
\hline
\end{tabular}

*15 without age information; **30 without age information; ***1 without age information; ' 88 without region information; "140 without region information

Table 2 also identifies the transportation accidents that occurred in the municipality of São Paulo by macro-regions in the years 2005, 2010, and 2015. The highest LTA fatalities were observed in the south $(23.8 \%)$, east $(22 \%)$, north $(21.6 \%)$, and southeast $(21 \%)$ regions. The lowest mortalities occurred in the west $(7.1 \%)$ and center (3\%) regions.

The results presented in Table 3 show a significant decrease in the standardized coefficients of general mortality from LTA per 100,000 inhabitants in most of the regions studied, in comparing the three periods examined.

\begin{tabular}{|c|c|c|c|c|c|}
\hline \multirow[b]{2}{*}{ Region } & \multicolumn{3}{|c|}{ Year } & & \\
\hline & 2005 & 2010 & 2015 & $\begin{array}{c}\text { SC (\%) } \\
\text { Mean }\end{array}$ & Chi-Square Test \\
\hline South & 13.5 & 15.1 & 10.6 & 13.1 & $\begin{array}{l}X 2=17.88 \\
(p=0.0005)^{\star}\end{array}$ \\
\hline Southeast & 12.9 & 10.3 & 8.9 & 10.7 & $\begin{array}{l}X 2=13.29 \\
(p=0.0040)^{*}\end{array}$ \\
\hline North & 12.4 & 13.2 & 9.9 & 11.8 & $\begin{array}{c}X 2=3.26 \\
(p=0.5153)\end{array}$ \\
\hline West & 3.4 & 4.0 & 4.1 & 3.8 & $\begin{array}{c}X 2=2.83 \\
(p=0.5870)\end{array}$ \\
\hline Central & 1.3 & 2.2 & 1.2 & 1.6 & $\begin{array}{c}X 2=5.92 \\
(p=0.1156)\end{array}$ \\
\hline East & 12.5 & 13.7 & 8.7 & 11.6 & $\begin{array}{c}X 2=14.25 \\
(p=0.0025)^{*}\end{array}$ \\
\hline
\end{tabular}

The southeast (12.9 - 8.9) and east (12.5 - 8.7) regions presented the greatest decrease in coefficients, showing a statistically significant reduction of $31.3 \%(p=0.0040)$ and $30.4 \%(p=0.0025)$ respectively, followed by the south region, with an also significant decrease of $21.8 \%(13.5-10.6)(p=0.0005)$. The reduction also happened in the north (12.4 - 9.9) and center (1.3 - 1.2) regions $-20.2 \%$ and $7.7 \%$ respectively - but were not considered representative or statistically significant. And in the west region (3.4 - 4.1) there was an increase of $20.5 \%$, considered not statistically significant too.

\section{DISCUSSION}

Among the components of external causes, LTA contribute significantly to high mortality in all societies, affecting all individuals without distinction. ${ }^{3}$

When investigating the mortality results according to age group (Table 2), individuals younger than 15 years and older than 55 years had much lower rates compared to the other groups with age groups between 20 and 54 years that had the highest rates.
Similar differences when comparing age extremes have been reported by other authors.,12 Except for those aged 55-64 years, which showed a significant increase of $44.9 \%$ and those aged 75 and over with 5.9\% from 2005 to 2015, there was a decrease or maintenance of mortality in all age groups.

The impact of more than one million Years of Potential Life Lost (YPLL) by LTA, especially within the young and productive age group (early mortality), in just one year in the country, represents an extreme social cost resulting from a death cause that could be prevented. Thus, greater advances in the prevention of mortality from LTA are necessary, considering the complexity of the factors involved and the unequal and iniquitous distribution of this problem in the Brazilian population. ${ }^{1}$ However, the accidents among males, which have not shown significant decreases in the rates, are of extreme relevance. The association among male gender, exposure to traffic accidents and mortality from this cause has been reported by several authors, as well as a tendency of temporal decrease among men and stabilization of rates among women. 8,13,14

In our study we did not find an equivalent reduction in rates for both sexes (Table 2), with a drop of approximately $3 \%$ for males and an increase of 1\% for females in the years 2010 and 2015. And when we evaluated the period from 2005 to 2015 we found a decrease of $2.3 \%$ for females and an increase of $0.6 \%$ for males.

According to Nardoto's study, men tend to be more violent due to cultural and biological injunctions, being thus more vulnerable to death by external causes, such as driving vehicles at higher speeds, riskier maneuvers, alcohol use, among others. ${ }^{6,15}$ ATTs may be associated with several factors, such as deficient conservation of vehicles and roads, human error and consumption of psychoactive substances. Evidence shows a causal link between the consumption of alcoholic beverages and the occurrence of traffic accidents, considering the effects of this substance on the perception, vision, reflexes, consciousness and behavior of individuals who stop using seat belts and drive at high speed. In Brazil, until recently, the high rates of traffic accidents have always been associated with the lack of both legislation and adequate public policies in relation to this phenomenon. ${ }^{16,17}$

The reduction of the standardized mortality coefficient in the city of São Paulo found in our study (Table 3), in most of the regions studied, follows a worldwide trend. This decrease can be explained by the reduction in the average speed on urban roads resulting from the increase in the car and motorcycle fleet that occurred during the study period.

However the increase in the period from 2005 to 2015 was mainly due to the acquisition of cars and motorcycles, resulting from economic incentives such as tax exemption and increased availability of financing for the acquisition of these means of transportation. ${ }^{18}$ Moreover, there was an increase in the purchasing power of middleand lower-income populations, which encouraged the acquisition of individual private vehicles for their travel, due to the exemption of the Tax on Industrialized Products (IPI) for new vehicles. ${ }^{7,19}$

Preventive actions in traffic - such as the modification of the Lei Seca (Dry Law) in December 2012 (Law No. 12,760/2012), awareness campaigns, and stricter inspection of traffic infractions in the São Paulo capital - may also have influenced the stabilization of the coefficients analyzed. ${ }^{14,20}$

The law that deals with the prohibition of alcohol use in traffic has undergone intense reformulation, succeeding in decreasing the rate of alcohol use through breathalyzer tests, as well as greater rigor in the application of penalties. ${ }^{21}$ Such measures were more intense between 2007 and 2013, especially during holidays and weekends, which may explain the decrease in these rates. ${ }^{22}$

The implementation of the new Brazilian Traffic Code, in effect since 1998, reduced traffic deaths in Brazil by up to $5.8 \%$, representing 
more than 26,300 lives saved, which is significant. In addition, there were savings of $R \$ 71$ billion in lost production, health care, removal and transportation between 1998 and $2004 .{ }^{4}$

Studies showing the impact of specific public policies on the occurrence of traffic accidents are relevant, since they indicate both the public authorities and the general population the scope and effectiveness of the legal measures instituted. ${ }^{2}$ The Ministry of Health develops several actions to address traffic violence. However, articulated and intersectoral actions involving the whole society are necessary, aiming to meet the goals of reducing morbidity and mortality from traffic accidents established in the Decade of Action for Road Safety from 2011 to $2020 .^{23}$

An important limitation of this study concerns the use of secondary data. This hinders the control of possible confounding factors and the reliability of the information, which directly depends on the coverage and quality of death notification. Regarding the coverage of death records, although there are still gaps in data collection, these have decreased in Brazil, so that data have become increasingly reliable. ${ }^{7}$

We observed differences in magnitude and trend in the different regions of the municipality of São Paulo focused on the groups and regions at higher risk and with an increasing trend, as was the case in the western region, known for its large number of bars and frequented by many young people. The discrepancies between the results for the different regions of the city show that there is a need to carefully study the characteristics of each region so that health policies aimed at the prevention of LTA can be based on the reality of each region. Thus, LTAs continue to be a public health problem in the city of São Paulo, due to the high burden of morbidity and mortality, the economic costs, and the social impact, mainly due to the involvement of individuals in productive age.

Through the results of this research, it is evident that actions to promote and prevent traffic accidents should primarily focus on young males who live or visit peripheral neighborhoods (south, north and east). We can state that the results show that the laws referring to the Brazilian Traffic Code (CTB) and Prohibition Law have been determinant for the prevention of deaths by traffic accidents in the municipality of São Paulo.

\section{CONCLUSION}

The results obtained by comparing the years examined indicate there is a decrease in overall mortality of RTAs in most macro-regions. This resulted from preventive actions in traffic, such as the modification of the Prohibition Law, awareness campaigns and stricter inspection of traffic violations in the capital of the state of São Paulo. However, regarding actions to prevent traffic accidents, young males living in peripheral neighborhoods of the city (south, north and east) are the most susceptible group, and thus deserve further attention, according to the data analysis.

CONTRIBUTIONS OF THE AUTHORS: Each author contributed individually and significantly to the development of this article. FBT: study conception; RSS: writing of the study and final approval of the manuscript to be published; JJSHEB: data interpretation and writing of the study; JVS: data interpretation and writing of the study; MBSS: critical review of the intellectual content and writing of the study; PCS: study design and final approval of the manuscript to be published.

\section{REFERENCES}

1. Andrade SSCA, Mello-Jorge MHP. Mortalidade e anos potenciais de vida perdidos por acidentes de transporte no Brasil, 2013. Rev Saude Publica. 2016;50:59

2. Abreu DROM, Souza EM, Mathias TAF. Impacto do Código de Trânsito Brasileiro e da Lei Seca na mortalidade por acidentes de trânsito. Cad Saude Publica. 2018;34(8):e00122117.

3. Oliveira NLB, Souza EM, Cunha GZ. Mortality in traffic accidentes: temporary trend between 1996 and 2012. Cienc Cuid Saude. 2017;16(4):1-8.

4. Leitão PA, Bezerra IMP, Santos EFS, Ribeiro SL, Takasu JM, Carlesso JL, et al. Mortality due to traffic accidents, before and after the reduction of the average speed of motor vehicles in the city of São Paulo, Brazil, from 2010 to 2016. J Hum Growth Dev. 2019;29(1):83-92.

5. Moreira MR, Ribeiro JM, Motta CT, Motta JIJ. Mortalidade por acidentes de transporte de trânsito em adolescentes e jovens, Brasil, 1996-2015: cumpriremos o ODS 3.6? Cien Saude Colet. 2018;23(9):2785-96.

6. Cover DP, Nunes EAB, Carvalho KM. Mortalidade por acidentes de trânsito no Piauí: caracterização de casos no biênio 2012-2013. Rev Uninga. 2016 Jul-Sep;49:12-9.

7. Aquino EC, Neves M, Morais Neto OL. Tendências da mortalidade por acidentes de transporte terrestre no município de Goiânia, Brasil, 2006-2014..Epidemiol Serv Saude. 2018;27(4):e2017268.

8. Klabunde FC, Ghizzo Filho J, Freitas PF, Nazário NO. Impacto da Lei Seca na taxa de mortalidade por acidentes de trânsito, Santa Catarina, entre 2005 e 2011. Arq Catarin Med. 2017;46(2):108-17.

9. Ministério da Saúde (BR). Sistema de Informação de Mortalidade - SIM [Internet]. Brasília: Ministério da Saúde; 1975 - [accessed on 2019 Mar 11]. Available from: http://www2.datasus.gov.br/DATASUS/index.php?area=090 $1 \&$ item $=1 \&$ acao $=26 \&$ pad $=31655$

10. Juliano Y, Novo NF, Goihman S, Paiva ER, Leser W. Coeficiente padronizado de anos de vida perdidos, de Haenszel. Comparação com o coeficiente padronizado de mortalidade geral, quanto à utilização como indicador de nível de saúde de populações. Rev Saude Pública. 1987;21(2):108-22.

11. Cochran WG. Some methods for strengtering the comman $X^{2}$ test. Biometrics. 1954;10(4):417-51.

12. Oliveira ZC, Mota ELA, Costa MCN. Evolução dos acidentes de trânsito em um grande centro urbano, 1991-2000. Cad Saude Publica. 2008;4(2):364-72.
13. Mesquita Filho M, Silva FM, Veiga VT. Acidentes de trânsito ocorridos antes e depois da legislação restritiva ao consumo de bebidas alcoólicas. Rev Med Minas Gerais. 2012;22(3):259-64.

14. Bacchieri G, Barros AJD. Acidentes de trânsito no Brasil de 1998 a 2010: muitas mudanças e poucos resultados. Rev Saude Publica. 2011;45(5):949-63.

15. Nardo EML, Diniz JMT, Cunha CEG. Perfil da vítima atendida pelo serviço pré-hospitalar aéreo de Pernambuco. Rev Esc Enferm. 2011;45(1):237-42.

16. Nunes MN, Nascimento LFC. Análise espacial de óbitos por acidentes de trânsito, antes e após a Lei Seca, nas microrregiões do estado de São Paulo. Rev Assoc Med Bras. 2012;58(6):685-90.

17. Cunha FV, Julien TMS, Santos JCS. Characterization of car accidents in the city of Guaratinguetá, Brazil involving motorcycles. Rev Enferm UFPE. 2011;5(5):1112-20.

18. Morais Neto OL, Beniz LAF, Rodrigues FR, Botacin CF, Mandacarú PMP, Oliveira IV, et al. Tendências de mortalidade por acidentes de trânsito pós redução de IPI. Rev Goiana Med. 2016;49(1):6-10.

19. Instituto de Pesquisa Econômica Aplicada (BR). Nota técnica: impactos da redução do imposto sobre produtos industrializados (IPI) de automóveis [Internet]. Brasília: Instituto de Pesquisa Econômica Aplicada; 2009 [accessed on 2018 Jul 10]. Available from: http://ipea.gov.br/agencia/ images/stories/ PDFs/2009_nt015_agosto_dimac.pdf

20. Brasil. Lei $n^{\circ}$ 12.760, de 20 de dezembro de 2012. Altera a Lei n⒐503, de 23 de setembro de 1997, que institui o Código de Trânsito Brasileiro. Diário Oficial da União. 2012 Dez 21;1:1.

21. Alves ACBB, Oliveira AS, Pedro JB, Mamlak L, Oliveira LS, Mendonça LO, et al. A nova lei seca: mudanças ocasionadas pela antiga e nova lei no código de trânsito brasileiro. Cad Grad Cienc Hum Sociais. 2014;2(2):137-46.

22. Malta DC, Berna RTI, Silva MMA, Claro RM, Silva JB Jr., Reis AAC. Consumo de bebidas alcoólicas e direção de veículos, balanço da lei seca, Brasil 2007 a 2013. Rev Saude Publica. 2014;48(4):692-6.

23. World Health Organization, United Nations Road Safety Collaboration. Global Plan for the Decade of Action for Road Safety, 2011-2020 [Internet]. Geneva: World Health Organization; 2010 [accessed on 2020 Apr 15]. Available from: https://www.who.int/roadsafety/decade_of_action/plan/en/ 